\title{
PROSES PEMBUATAN BRIKET BERBASIS KULIT SINGKONG DAN KAJIAN EKSPERIMEN PARAMETRIS PENGARUH BAHAN PEREKATNYA TERHADAP NILAI KALOR DAN LAJU PEMBAKARAN
}

\author{
Jenny Delly ${ }^{1}$, Nersan Saputra ${ }^{2}$ \\ ${ }^{1}$ Staf Pengajar Program Studi Teknik Mesin Fakultas Teknik Universitas Halu Oleo \\ Kampus Hijau Bumi Tridarma Andounohu Kendari 93232 \\ ${ }^{2}$ Mahasiswa Program Studi Teknik Mesin Fakultas Teknik Universitas Halu Oleo \\ Kampus Hijau Bumi Tridarma Andounohu Kendari 93232 \\ E-mail: jennydelly@gmail.com
}

\begin{abstract}
Teknologi briket berbasis kulit singkong dapat berkontibusi dalam mengurangi ketergantungan terhadap bahan bakar konvensional dan dalam menjaga kelestarian lingkungan. Salah satu bagian penting dalam menentukan kualitas briket sebagai bahan bakar adalah bahan perekat. Tujuan penelitian ini adalah untuk untuk mengetahui pengaruh bahan perekat terhadap laju pembakaran dan nilai kalor briket kulit singkong dan untuk menjelaskan proses pembuatanya. Metodologi yang digunakan dalam penelitian ini adalah eksperimen pada benda uji briket kulit singkong. Hasil dari penelitian ini menunjukan bahwa briket dengan perekat tepung tapioka memiliki nilai kalor yang terbesar (180.8749 $\mathrm{J} / \mathrm{gr}$ ), diikuti oleh briket dengan perekat tanah liat (143.1996 J/gr ) dan briket dengan perekat tepung sagu (128.6978 $\mathrm{J} / \mathrm{gr}$ ). Laju pembakaran dengan perekat tanah liat adalah $0.56 \mathrm{gr} / \mathrm{menit}$, sedangkan briket dengan perekat tepung sagu adalah $0.43 \mathrm{gr} / \mathrm{menit}$ dan briket dengan perekat tepung tapioka adalah $0.36 \mathrm{gr} / \mathrm{menit}$. Proses pembuatan briket berbasis kulit singkong juga dijelaskan mendalam dalam artikel ini.
\end{abstract}

Keywords : briket, kulit singkong, perekat, laju pembakaran, nilai kalor

\begin{abstract}
Abstrak
The process of making the briquette technology based on the cassava peel and its parametrical experiment on the effect of the adhesive on the combustion rate and the heating value. Cassava peel-based on briquette technology can significantly contribute to reduce the dependence on the conventional fuels and to protect the environment. One of the important aspects in determining the quality of the briquettes as fuel is the adhesive. The purposes of this study are to determine the effect of the adhesive materials on the combustion rate and the heating value of the cassave peel briquette and to explain its manufacturing process. The methodology utilised in this study is an experiment on the briquette cassava peel. The results of this study indicate that the briquette based on the adhesice-tapioca flour has the highest calorific value $(180.8749 \mathrm{~J} / \mathrm{g})$, followed by that of the briquette based on the adhesive clay $(143.1996 \mathrm{~J} / \mathrm{g})$ and the briquette based on the adhesive corn $(128.6978 \mathrm{~J} / \mathrm{g})$. The combustion rate of the briquette with the adhesive clay is $0,56 \mathrm{gr} /$ minute, that of the briquette with the corn starch adhesive is $0,43 \mathrm{gr} /$ minute, and that of the briquette with the tapioca starch adhesive is $0,36 \mathrm{gr} /$ minute. The process of making the briquette based on the cassava peel is also described comphehensivelly in this article.
\end{abstract}

Kata Kunci: briquette, cassave peel, adhesive, haeting rate, heating value

\section{Pendahuluan}

Indonesia dikenal sebagai salah satu negara OPEC, organisasi penghasil minyak dunia. Akan tetapi, sejak tahun 2003, Indonesia telah berubah menjadi negara pengimpor minyak. Kebutuhan energi di zaman yang semakin maju ini terus mengalami peningkatan, dan hingga saat ini masyarakat masih 
bergantung pada sumber energi yang berasal dari fosil, misalnya minyak tanah, solar, bensin dan batubara.

Minyak bumi adalah sumber energi yang tidak dapat diperbaharui, tetapi dalam kehidupan seharihari bahan bakar minyak masih menjadi pilihan utama. Hal ini dapat mengakibatkan menipisnya cadangan minyak bumi. Dengan menipisnya cadangan minyak bumi tidak menutup kemungkinan nantinya negara kita mengalami krisis energi. Untuk mengantisipasi krisis energi maka diperlukan pengembangan sumber-sumber daya energi alternatif.

Untuk mendukung hal ini, pemerintah telah menerbitkan Peraturan Presiden Republik Indonesia nomor 5 tahun 2006 tentang kebijakan energi nasional untuk mengembangkan sumber energi alternatif sebagai pengganti bahan bakar minyak. Kebijakan tersebut menekankan pada sumber daya yang dapat diperbaharui sebagai pengganti bahan bakar minyak.

Beberapa potensi sumber energi alternatif yang dapat diperbaharui yang bisa dikembangkan antara lain energi matahari, energi angin, energi panas bumi, energi panas laut dan energi biomassa. Di antara sumber-sumber energi alternatif tersebut, energi biomassa merupakan sumber energi alternatif yang perlu mendapat prioritas dalam pengembangannya dibandingkan dengan sumber energi yang lain. Hal ini karena Indonesia sebagai negara agraris yang banyak menghasilkan limbah pertanian yang kurang termanfaatkan (KNSDG, 2010).

Salah satu hasil limbah pertanian yang dapat dimanfaatkan sebagai sumber energi adalah briket biomasa. Briket adalah bahan bakar alternatif yang menyerupai arang yang tersusun dari bahan non kayu. Banyak bahan-bahan yang dapat digunakan sebagai bahan baku untuk pembuatan briket, antara lain sekam padi, jerami, batok kelapa, serbuk gergaji dan dedaunan. Kulit singkong juga memiliki potensi sebagai bahan pembuatan briket di Indonesia karena ketersediaan hasil produk petanian singkong yang besar.

Dalam membuat teknologi briket, laju pembakaran dan nilai pembakaran merupakan aspek penting dalam menentukan kualitas briket. Aspek perekat dalam komposisi briket dapat memiliki peran penting dalam menentukan laju pembakaran dan nilai bakar. Tujuan penelitian ini adalah untuk mengetahui proses pembuatan briket kulit singkong dan untuk mengetahui pengaruh perekat pada nilai kalor dan laju pembakaran briket kulit singkong.

\section{Kajian Literatur}

\section{Biomassa sebagai sumber energi}

Biomassa adalah suatu limbah benda padat yang bisa dimanfaatkan sebagai sumber bahan bakar. Biomassa meliputi limbah kayu, limbah pertanian, limbah perkebunan, limbah hutan dan komponen organik dari industri dan rumah tangga. Energi biomassa dapat menjadi sumber energi alternatif pengganti bahan bakar fosil (minyak bumi) karena sifatnya yang dapat diperbaharui dan relatif tidak mengandung unsur sulfur sehingga tidak menyebabkan polusi udara (Sinurat, 2011).

Tabel 1. Potensi energi biomassa di Indonesia ( Sumber : Abdul Kadir, 1995)

\begin{tabular}{llll}
\hline Sumber energi & $\begin{array}{c}\text { Produksi } \\
(\mathbf{1 0 6} \text { ton/th })\end{array}$ & $\begin{array}{c}\text { Energi } \\
(\mathbf{1 0 9} \text { ton/th })\end{array}$ & $\begin{array}{c}\text { Pangsa } \\
(\boldsymbol{\%})\end{array}$ \\
\hline Kayu & 25.00 & 100 & 72.0 \\
\hline Sekam Padi & 7.55 & 27.0 & 19.4 \\
\hline Jenggal Jagung & 1.52 & 6.8 & 4.9 \\
\hline $\begin{array}{l}\text { Tempurung } \\
\text { Kelapa }\end{array}$ & 1.25 & 5.1 & 3.4 \\
\hline Potensi Total & 35.32 & 138.9 & 100 \\
\hline
\end{tabular}

Salah satu aspek penting dalam pengembangan biomasa adalah teknologi konversi biomassa. Setiap teknologi konversi biomassa memiliki perbedaan pada alat yang digunakan untuk mengkonversi biomassa dan juga dapat menghasilkan perbedaan jenis bahan bakar yang dihasilkan.Secara umum teknologi konversi biomassa menjadi bahan bakar dapat dibedakan menjadi tiga (Hidayah, 2004). Pertama adalah pembakaran langsung, yang merupakan teknologi yang paling sederhana karena pada umumnya biomassa telah dapat langsung dibakar. Beberapa biomassa perlu dikeringkan terlebih dahulu dan didensifikasi untuk kepraktisan dalam penggunaan. Kedua adalah konversi termokimiawi, yang merupakan teknologi yang memerlukan perlakuan termal untuk memicu terjadinya reaksi 
kimia dalam menghasilkan bahan bakar. Contoh dari teknologi ini adalah proses pirolisis dan gasifikasi. Ketiga adalah konversi biokimiawi yang merupakan teknologi konversi yang menggunakan bantuan mikroba dalam menghasilkan bahan bakar. Konversi biokimia menghasilkan gas metan dan etanol yang dapat dimanfaatkan sebagai bahan bakar.

\section{Kulit singkong}

Singkong yang memiliki nama latin Manihot Utilissima, merupakan umbi atau akar pohon yang panjang dengan fisik rata-rata bergaris tengah 2-3 $\mathrm{cm}$ dan panjang $50-80 \mathrm{~cm}$. Daging umbinya berwarna putih atau kekuning-kuningan. Produksi singkong di Indonesia sangat besar. Pada tahun 2008 Indonesia merupakan negara ketiga penghasil singkong terbesar di dunia (Wikipedia, 2008). Sebagai negara penghasil singkong maka potensi limbah kulit singkong juga besar.

Presentase jumlah limbah kulit bagian luar sebesar 0,5-2\% dari berat total singkong segar dan limbah kulit bagian dalam sebesar 8-15\% (gambar 1). Sampah kulit singkong termasuk dalam kategori sampah organik karena sampah ini dapat terdegradasi (membusuk) secara alami (Wikipedia 2008).

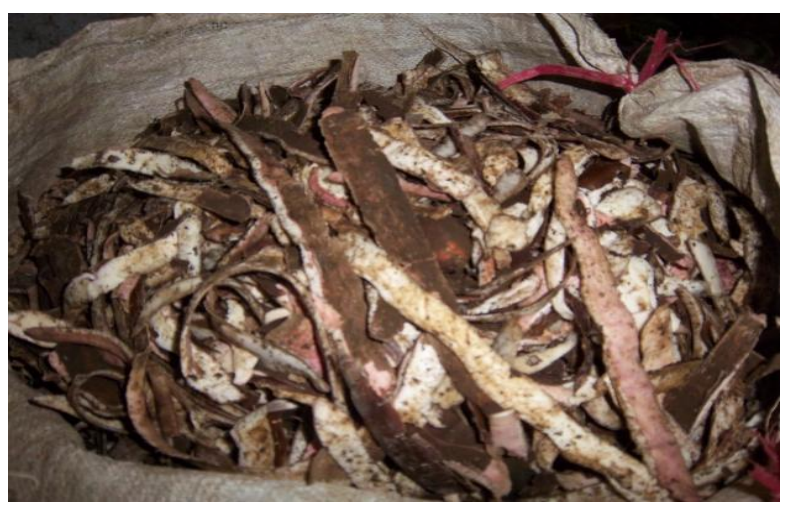

Gambar 1. Limbah kulit singkong (Sumber: Wikipedia, 2008)

\section{Briket bioarang}

Bioarang merupakan arang yang dibuat dari aneka macam bahan hayati atau biomassa, misalnya kayu, ranting, daun-daunan, rumput jerami dan limbah pertanian lainnya. Bioarang dapat digunakan melalui proses pengolahan, salah satunya adalah menjadi briket bioarang (Sinurat, 2011).

Faktor-faktor yang mempengaruhi sifat briket arang adalah berat jenis bahan bakar atau berat jenis serbuk arang, kehalusan serbuk, suhu karbonisasi dan tekanan pada saat dilakukan pencetakan (Sinurat, 2011).

\section{Parameter kualitas briket bioarang}

Beberapa parameter kualitas briket yang mempengaruhi pemanfaatannya antara lain kadar air, kadar abu dan zat kandungan terbuang. Kadar air bahan bakar padat adalah perbandingan berat air yang terkandung bahan bakar padat terhadap berat kering bahan bakar padat tersebut (Ndara, 2010).

Abu adalah zat tinggal, yang merupakan kandungan zat anorganik pada briket yang dapat ditentukan jumlahnya sebagai berat yang tinggal apabila briket dibakar secara sempurna. Abu briket berasal dari clay, pasir dan zat mineral lainnya. Briket dengan kandungan abu yang tinggi sangat tidak menguntungkan karena akan membentuk kerak (Ndara, 2010 ).

Zat terbang terdiri dari gas-gas yang mudah terbakar seperti hidrogen, karbon monoksida (CO), dan metana $\left(\mathrm{CH}_{4}\right)$, tetapi kadang-kadang terdapat juga gas-gas yang tidak terbakar seperti $\mathrm{CO}_{2}$ dan $\mathrm{H}_{2} \mathrm{O}$ (Ndara, 2010).

Nilai kalor adalah nilai yang menyatakan jumlah energi panas maksimum yang dibebaskan oleh suatu bahan bakar melalui reaksi pembakaran sempurna persatuan massa atau volume bahan bakar tersebut. Nilai kalor berhubungan langsung dengan kadar $\mathrm{C}$ dan $\mathrm{H}$ yang dikandung oleh bahan bakar padat. Semakin besar kadar keduanya, akan semakin besar nilai kalor yang dikandung (Ndara, 2010).

Tabel 4. Kualitas Mutu Briket Bioarang (Sumber : Ndraha 2010)

\begin{tabular}{ccc}
\hline Sifat & Briket Arang Inggris & $\begin{array}{c}\text { Briket Arang } \\
\text { Jepang }\end{array}$ \\
\hline Kadar Air & 3.59 & 6 \\
\hline Kadar Abu & 8.26 & $3-6$ \\
\hline Nilai Kalor & 7289.00 & $6000-7000$ \\
\hline
\end{tabular}




\section{Bahan perekat briket}

Sifat ilmiah bubuk arang cenderung saling memisah. Dengan bantuan bahan perekat atau lem, butir-butir arang dapat disatukan dan dibentuk. Namun permasalahannya terletak pada jenis bahan perekat yang akan dipilih. Penentuan bahan perekat yang digunakan sangat berpengaruh terhadap kualitas briket ketika dibakar dan dinyalakan (Yusuf, 2013).

Faktor harga dan ketersediaannya di pasaran harus dipertimbangkan secara seksama karena setiap bahan perekat memiliki daya lekat yang berbedabeda karakteristiknya. Beberapa karakteristik bahan baku perekat untuk pembuatan briket adalah memiliki gaya kohesi yang baik bila dicampur dengan bahan induk, mudah terbakar, tidak berasap, mudah didapat dalam jumlah banyak, murah harganya, tidak mengeluarkan bau, tidak beracun dan tidak berbahaya (Wijayamti, 2009).

Jenis bahan baku yang umum dipakai sebagai pengikat untuk pembuatan briket, yaitu perekat anorganik (semen, lempung dan natrium silikat) dan perekat organik (kanji, tar, aspal, amilum, molase dan paraffin). Jumlah perekat yang digunakan dalam pembuatan briket bioarang adalah sebanyak $10 \%$ dari berat arang yang akan digunakan dalam pembuatan briket tersebut. (Ndraha, 2010).

Lempung atau tanah liat umumnya juga banyak digunakan sebagai bahan perekat briket. Jenis-jenis lempung yang dapat dipakai untuk pembuatan briket terdiri dari jenis lempung warna kemerahmerahan, kekuning-kuningan dan abu-abu (Wijayanti, 2009).

Perekat tapioka juga dapat digunakan sebagai bahan perekat pada briket arang karena banyak terdapat di pasaran dan harganya relatif murah. Perekat ini dalam penggunaannya menimbulkan asap yang relatif sedikit dibandingkan bahan lainnya. Dalam sebuah penelitian, menunjukkan bahwa briket arang dengan tepung tapioka kanji sebagai bahan perekat akan sedikit menurunkan nilai kalornya bila dibandingkan dengan nilai kalor kayu dalam bentuk aslinya ( Ndara, 2010).

Getah karet juga telah digunakan sebagai perekat briket. Daya lekat getah karet lebih kuat dibandingkan dengan tanah liat dan tapioka. Namun biaya produksinya lebih mahal dan sulit mendapatkannya. Briket dengan perekat jenis ini akan menghasilkan asap tebal berwarna hitam dan beraroma kurang sedap bila dibakar (Ndraha 2010).

\section{Proses karbonisasi}

Proses karbonisasi atau pengarangan adalah proses mengubah bahan baku asal menjadi karbon berwarna hitam melalui pembakaran dalam ruang tertutup dengan udara yang terbatas atau seminimal mungkin (Wijayanti, 2009).

Dalam pengarangan, energi pada bahan akan dibebaskan secara perlahan. Apabila proses pembakaran dihentikan secara tiba-tiba ketika bahan masih membara, bahan tersebut akan menjadi arang yang berwarna kehitaman. Dalam bahan tersebut masih terdapat sisa energi yang dapat dimanfaatkan untuk berbagai keperluan, seperti memasak, memanggang dan mengeringkan. Bahan organik yang sudah menjadi arang tersebut akan mengeluarkan sedikit asap dibandingkan dibakar langsung menjadi abu. Lamanya pengarangan ditentukan oleh jumlah atau volume bahan organik, ukuran parsial bahan, kerapatan bahan, tingkat kekeringan bahan, jumlah oksigen yang masuk dan asap yang keluar dari ruang pembakaran (Fatimah, 2004).

Salah satu metode pengarangan adalah dengan pirolisis. Pengarangan menggunakan alat pirolisis cukup praktis karena bahan baku tidak perlu ditunggu terus-menerus sampai menjadi arang, namun yang perlu diperhatikan dalam metode ini adalah asapnya. (Ndraha , 2010).

\section{Metodologi Penelitian}

\section{Lokasi penelitian}

Penelitian ini dilakukan di Laboratorium Teknologi Mekanik Fakultas Teknik Universitas Halu Oleo Kendari. Pelaksanaan pengujian briket dilakukan di Laboratorium Kimia, Fakultas Matematika dan Ilmu Pengetahuan Alam Universitas Halu Oleo. Penelitian ini dilaksanakan pada bulan Maret - Mei 2014.

\section{Alat dan bahan}

Alat yang digunakan dalam penelitian ini adalah timbangan, kompor, lumpung, alu, mesh 100, alat pres briket, cetakan briket, jangka sorong dan tungku. Bahan yang digunakan adalah kulit singkong sebagai bahan untuk pembuatan briket, tepung kanji, tepung sagu dan tanah liat sebagai 
bahan perekat briket kulit singkong dan air sebagai bahan pelarut bahan perekat.

\section{Pengujian briket}

Dalam penelitian ini dilaksanakan beberapa pengujian, seperti uji proksimasi, uji masa jenis, uji pembakaran dan uji kadar abu. Uji proksimasi adalah metode untuk mengetahui kadar air, kadar karbon, kadar sulfur dan nilai kalor briket.

Untuk menghitung massa jenis briket $(\rho)$ dapat dilakukan dengan persamaan berikut:

$\rho=\frac{\mathrm{m}}{\mathrm{V}}$

Dimana :

$\rho \quad$ : Kerapatan $\left(\mathrm{gram} / \mathrm{cm}^{3}\right)$

$\mathrm{m}$ : Massa (gram)

$\mathrm{V}$ : Volume briket $\left(\mathrm{cm}^{3}\right)$

Uji pembakaran dilakukan untuk mengetahui berapa lama waktu briket habis sampai menjadi abu, dan berapa lama waktu yang dibutuhkan untuk mendidihkan 1 liter air. Laju pembakaran $\left(L_{P}\right)$ dapat dihitung dengan menggunakan rumus sebagai berikut,

$\mathrm{L}_{\mathrm{P}}=\frac{\text { Berat briket (gram) }}{\text { Waktu sampai briket habis (detik) }}$

Kadar abu dihitungan dengan menimbang berat briket yang akan dibakar, kemudian membakar briket tersebut sampai habis sehingga menjadi abu. Sisa pembakaran berupa abu tersebut kemudian ditimbang kembali. Untuk menghitungan kadar abu briket $\left(\mathrm{K}_{\mathrm{A}}\right)$, dapat digunakan rumus berikut :

$\mathrm{K}_{\mathrm{A}}=\frac{(\text { brt.abu }+ \text { brt.cawan })-(\text { brt.cawan })}{\text { berat samp el }} \times 100 \%$

\section{Diagram Alir}

Gambar 2 memperlihatkan diagram alir penelitian ini. Penelitian ini diawali dengan kajian literatur. Tahap selanjutnya adalah persiapan alat dan bahan dan proses karbonasi kulit singkong. Setelah proses ini dilanjutkan dengan penggilingan dan penyaringan dan pencampuran perekat tapioka, tepung sagu dan tanah liat dengan kulit singkong. Setelah proses ini dilanjutkan dengan pencetakan briket dan pengujian sebelum dilakukan proses analisa hasil.

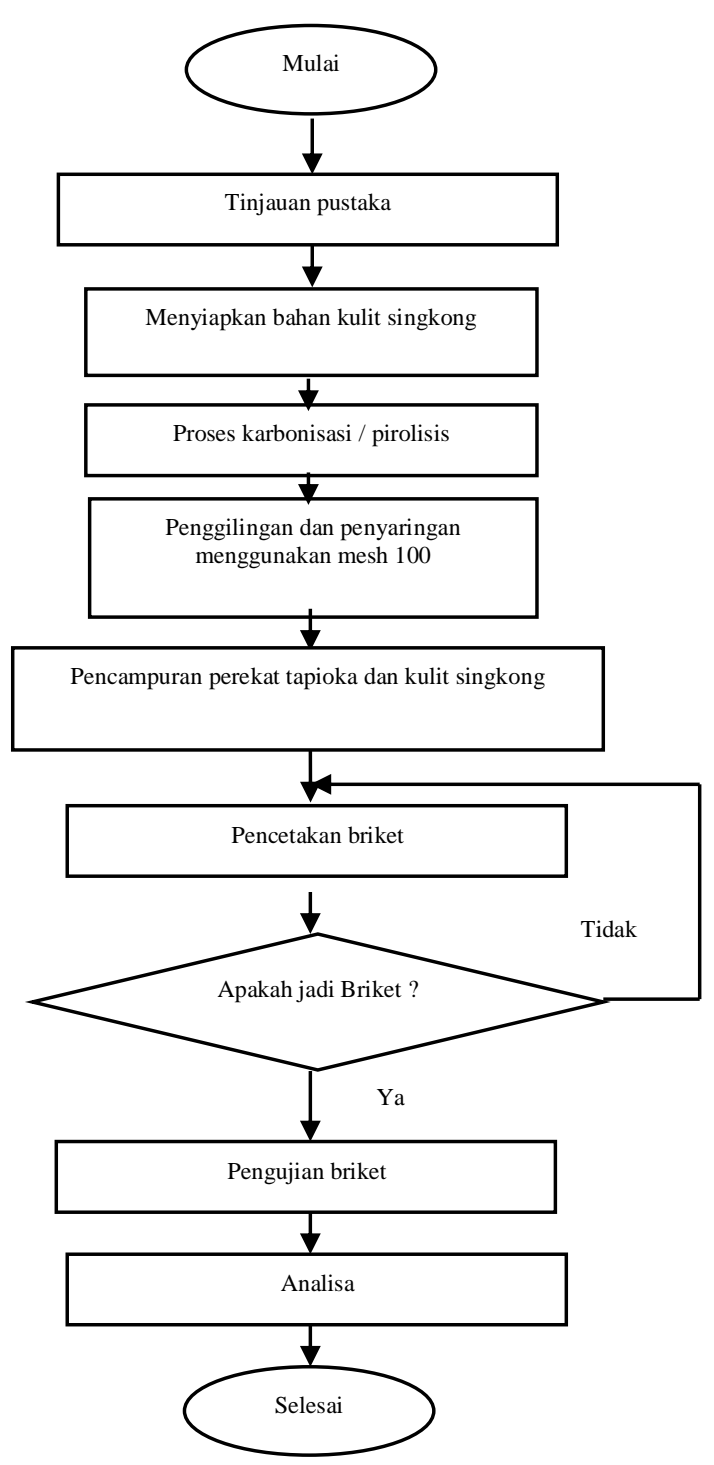

Gambar 2. Diagram alir penelitian

\section{Hasil dan Pembahasan}

\section{Pembuatan arang kulit singkong}

Poeses pembuatan briket kulit singkon diawali dengan proses pengarangan kulit singkong di dalam reaktor arang. Dalam proses ini, kulit singkong yang sudah dikeringkan, dimasukkan ke dalam reaktor. Sebanyak $1 \mathrm{~kg}$ kulit singkong, dapat menghasilkan arang sebanyak 570 gram. Proses pengarangan kulit singkong menjadi arang dari hasil pengamatan membutuhkan waktu sekitar 2 sampai 3 jam.

Arang yang diperoleh dari proses pengarangan dalam reaktor, selanjutnya dihaluskan. 
Penghalusan arang bertujuan untuk membuat butiran arang kulit singkong lebih halus agar lebih mudah diikat dengan bahan perekat.

Setelah proses ini, arang kulit singkong yang telah dihaluskan, dicampurkan dengan masing-masing perekat yaitu tepung tapioka, tepung sagu dan tanah liat, dengan perbandingan masa 100 (kulit) : 40 (perekat). Tepung tapioka dan tepung sagu masing-masing terlebih dahulu dicampur dengan air sebanyak $50 \mathrm{ml}$ kemudian panaskan di atas kompor sampai menjadi lem. Lem kemudian dicampurkan dengan arang kulit singkong yang telah dihaluskan dengan mesh 100. Pencampuran dilakukan sampai adonan merata.

Tanah liat yang akan digunakan sebagai perekat, pertama-tama dibersihkan dari kotoran dan diendapkan semalaman. Tanah liat yang telah diendapkan yang akan digunakan hanya pada bagian atasnya, yaitu bagian lembut yang tidak bercampur dengan pasir. Bagian tanah liat yang lembut tersebut mempunyai daya ikat yang lebih baik. Tanah liat yang lembut dicampurkan dengan arang kulit singkong yang telah dihaluskan dengan mesh 100 dalam keadaan basah.

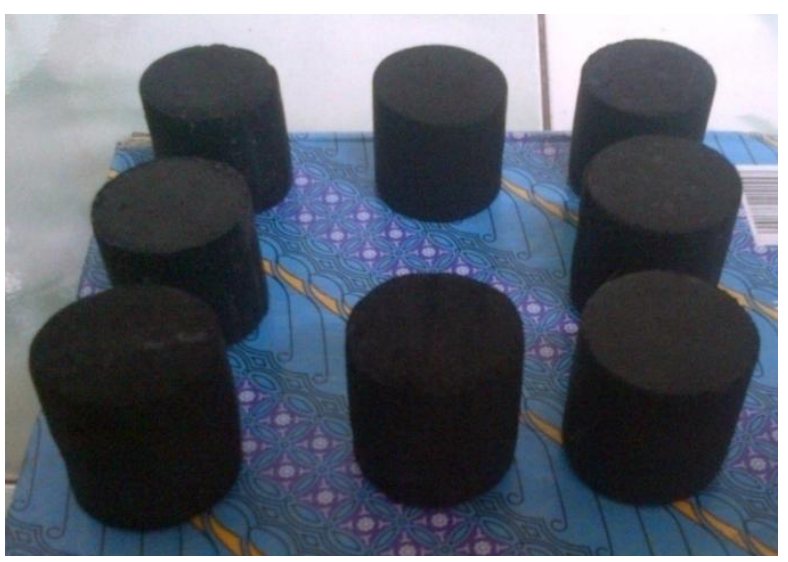

Gambar 3. Bentuk briket hasil penelitian

Metode pencampuran antara arang halus kulit singkong dengan masing-masing perekat akan menghasilkan campuran briket basah mendekati pasta. Selanjutnya briket basah seperti pasta dari masing-masing campuran arang halus kulit singkong dengan perekat, dimasukkan kedalam cetakan sebanyak 50 gram dan diberikan tekanan sebesar 2500 lbs. Setelah itu hasil cetakan dikeluarkan dan dilakukan penimbangan pada briket untuk mendapatkan berat awal briket kulit singkong dengan perekat tepung tapioka, tepung sagu dan tanah liat.

Setelah itu, dilakukan proses pengeringan briket dengan menggunakan sinar matahari sekitar 3 hari, kemudian penimbangan kembali terhadap briket yang telah dikeringkan untuk mendapatkan berat akhir briket. Hasil pembuatan briket dalam penelitian ini dapat dilihat pada gambar 3 .

\section{Kadar air briket kulit singkong}

Briket arang mempunyai sifat higroskopis yang tinggi. Perhitungan kadar air bertujuan untuk mengetahui sifat higroskopis briket hasil penelitian. Uji kadar air dilakukan dengan menimbang briket setelah proses pencetakkan kemudian mengeringkan briket. Setelah briket kering kemudian ditimbang kembali untuk mengetahui berat akhir briket.

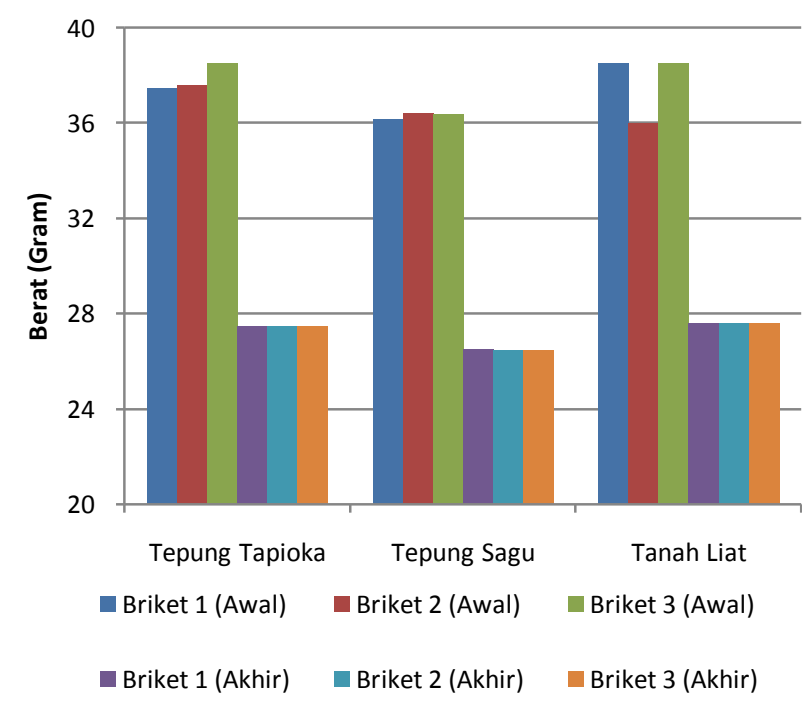

Gambar 4. Hasil penimbangan briet awal-akhir sebagai dasar penentuan kadar air

Berdasarkan hasil uji, nilai kadar air untuk perekat tepung tapioka adalah yang terbesar ( $27.42 \%)$, diikuti oleh perekat tepung sagu $(27.14 \%)$ dan untuk perekat tanah liat $(26.77 \%)$.

\section{Kerapatan briket kulit singkong}

Kerapatan menunjukkan perbandingan antara massa dan volume briket. Uji kerapatan dilakukan dengan mengukur tinggi dan diameter briket serta menimbang berat briket. Berdasarkan hasil uji 
kerapatan rata-rata, untuk perekat tepung tapioka sebesar $0.89 \mathrm{gr} / \mathrm{cm}^{3}$, perekat tepung sagu sebesar $0.90 \mathrm{gr} / \mathrm{cm}^{3}$ dan untuk perekat tanah liat sebesar $0.86 \mathrm{gr} / \mathrm{cm}^{3}$.

\section{Nilai kalor}

Berdasarkan hasil uji nilai kalor, untuk perekat tepung tapioka memiliki nilai terbesar (180.87 $\mathrm{J} / \mathrm{gr}$ ), perekat tepung sagu sebesar $128.69 \mathrm{~J} / \mathrm{gr}$, dan untuk perekat tanah liat sebesar $143.19 \mathrm{~J} / \mathrm{gr}$.

\section{Pembakaran briket kulit singkong}

Laju pembakaran adalah penggambaran berkurangnya berat per satuan waktu selama pembakaran. Uji pembakaran dilakukan dengan menimbang briket seberat 26 gr kemudian melakukan pembakaran awal selama 10 menit. Setelah itu briket diletakkan di dalam tungku sederhana untuk dihitung waktu pembakaran menggunakan stopwatch sampai briket habis menjadi abu.

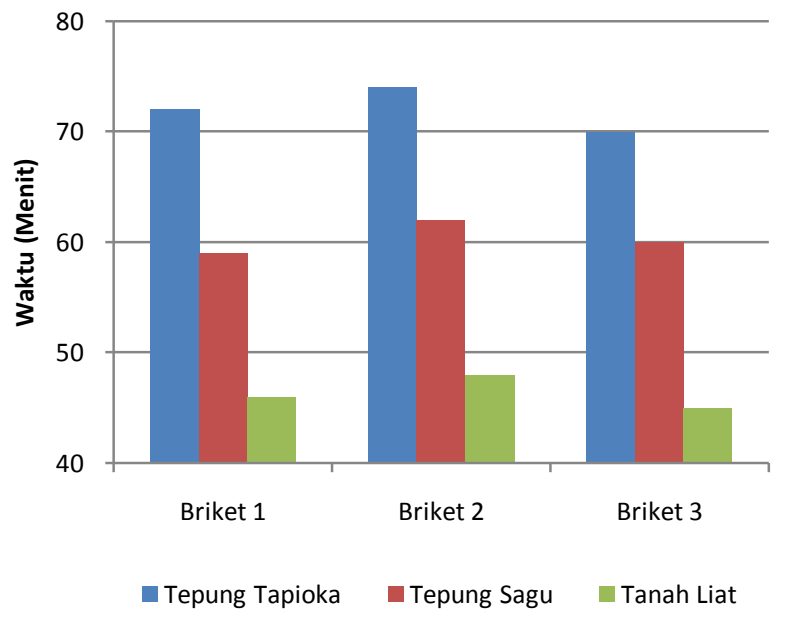

Gambar 5. Laju pembakaran briket kulit singkong

Gambar 5 menunjukan laju pembakaran briket kulit singkong pada variasi perekat. Dari gambar tersebut, waktu yang dibutuhkan oleh briket dengan perekat tepung tapioka adalah yang terbesar (sekitar 70 menit), diikuti oleh briket berperekat tepung sagu (sekitar 60 menit) dan tanah liat (sekitar 30 menit).

\section{Kadar abu briket kulit singkong}

Abu merupakan bagian yang tersisa dari hasil pembakaran. Gambar 6 menunjukan berat abu setelah pembakaran briket kulit singkong pada variasi perekat.

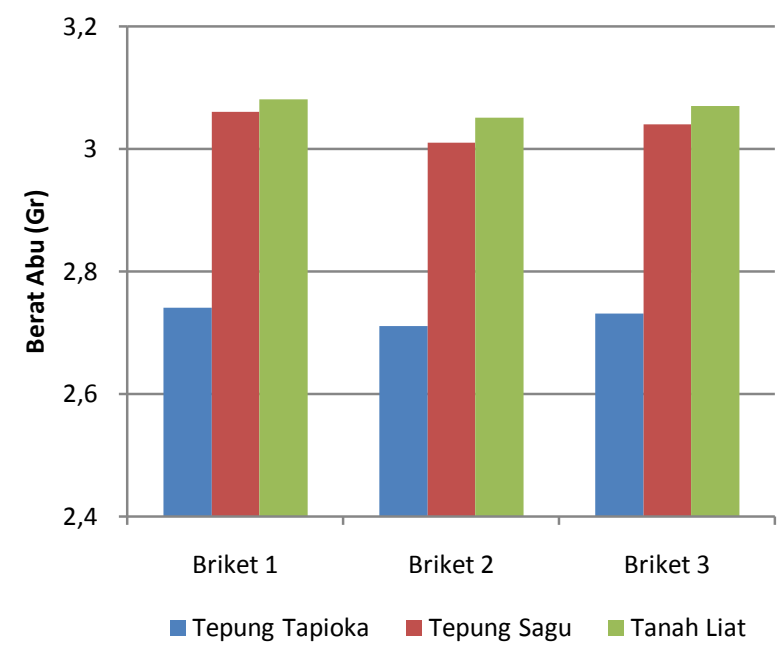

Gambar 6. Laju pembakaran briket kulit singkong

Dari gambar tersebut dapat dilihat bahwa berat abu terbesar didapatkan oleh briket berperekat tanah liat dan tepung sagu (sekitar 3 gram), diikuti oleh briket berperekat tepung tapioka (2,7 gram). Berdasarkan hasil uji berat abu tersebut, kadar abu rata-rata, untuk perekat tepung tapioka sebesar $10.48 \%$, untuk perekat tepung sagu sebesar 11.67 $\%$ dan untuk perekat tanah liat sebesar $11.79 \%$.

\section{Kesimpulan dan Saran}

Pada bagian berikut akan dijelaskan kesimpulan dalam penelitian ini. Dalam pembuatan briket singkong, diawali dengan proses pembersihan kotoran, proses pengeringan, proses pengarangan dan penghalusan. Setelah itu dilanjutkan dengan proses pencampuran dengan perekat, sebelum dilakukan pencetakan, penekanan dan pengeringan.

Dari hasil pengujian, briket dengan perekat tepung tapioka memiliki nilai kalor yang terbesar (180.8749 J/gr), diikuti oleh briket dengan perekat tanah liat (143.1996 J/gr) dan briket dengan perekat tepung sagu $(128.6978 \mathrm{~J} / \mathrm{gr})$. Dalam hal laju pembakaran, laju terbesar dimiliki oleh briket dengan perekat tanah liat $(0.56 \mathrm{gr} / \mathrm{menit})$, diikuti oleh briket berperekat tepung sagu $(0.43 \mathrm{gr} / \mathrm{menit})$ 
dan briket dengan perekat tepung tapioka $(0.3613$ $\mathrm{gr} / \mathrm{menit})$.

Saran yang dapat diberikan dalam penelitian ini adalah dalam proses pengeringan briket setelah dicetak, sebaiknya briket tidak dikeringkan dengan sinar matahari yang panas, karena dapat menyebabkan briket menjadi retak.

\section{Daftar Pustaka}

Fatimah I. 2004, "Pengaruh Laju Pemanasan Terhadap Komposisi Biofuel Hasil Pirolisis Serbuk Kayu”, Vol.1, No. 1. Fakultas Matematika dan Ilmu Pengetahuan Alam. Universitas Islam Indonesia.

Hidayah NF. 2012, "Pemanfaatan Limbah Kulit Singkong Menjadi kripik". http://datasmaku.blogspot.com/2012/10/karya-tulispemanfaatan-limbah-kulit_23.html. (diakses pada tanggal 18/1/2014, pukul 11:20).

Kadir A. 1995, "Energi: Sumber Daya, Inovasi, Tenaga Listrik, Potensi Ekonomi”, Cet.1. Edisi kedua/revisi. Jakarta: Universitas Indonesia.

KNSDG. 2010, "Pemberdayaan Sumber Daya Genetik sebagai Sumber Bahan Bakar Hayati".

http://indoplasma.or.id/berita/berita_2010_ apresiasi_ pengelolaanSDG_Juli2010.htm. (diakses pada tanggal 12/2/2014 pukul 21:23).

Ndraha N. 2010, "Uji komposisi bahan pembuat briket bioarang tempurung kelapa dan serbuk kayu terhadap mutu yang dihasilkan". Fakultas Pertanian. Universitas Sumatera Utara.

Sinurat E. 2011, "Studi pemanfaatan briket kulit jambu mete dan tongkol jagung sebagai bahan bakar alternatif". Fakultas Teknik. Universitas Hasanuddin. Makassar.

Wijayanti DS. 2009, "Karakteristik Briket Arang dari Serbuk Gergaji dengan Penambahan Arang Cangkang Kelapa Sawit”. Fakultas Pertanian. Universitas Sumatera Utara.

Wikipedia. 2013, "Ketela Pohon". http://id.wikipedia.org/wiki/Ketela_pohon, (diakses pada tanggal 18/1/2014, pukul 19:12).
Yusuf S. 2013, "Briket, Energi Terbarukan Pengganti Batu Bara".

http://muslimengineer1453.blogspot.com/20 13/03/briket-energi terbarukan-penggantibatu_16.html. (diakses pada tanggal 11/2/2014, pukul 22:20). 